FULL RESEARCH ARTICLE

\title{
Environmental values of California winegrape growers and the use of barn owl nest boxes as a tool for integrated pest management
}

\author{
BROOKS R. ESTES ${ }^{1 *}$ AND MATTHEW D. JOHNSON ${ }^{2}$
}

${ }^{1}$ Humboldt State University, Environment \& Community Program, 1 Harpst Street, Arcata, CA 95521, USA

${ }^{2}$ Humboldt State University, Wildlife Department, 1 Harpst Street, Arcata, CA 95521, USA *Corresponding Author: phoenix.leo@gmail.com

Synthetic pesticides from agriculture pose threats to biodiversity, and the adoption of alternative pest management is vital to meet rising crop demands while protecting native species. For example, the use of nest boxes for barn owls (Tyto furcata and T. alba) may help control rodent pests and reduce the use of rodenticides. However, the environmental perceptions of farmers and how receptive they are to alternative pest management practices remains uncertain. Traditionally, agricultural policies and programs have focused largely on the economic self-interest of farmers, but these narrow approaches have proven insufficient to describe and predict conservation behaviors, and the study of environmental value orientations (EVOs) may better explain farmers' adoption of novel wildlife-friendly practices. The study of EVOs can help identify people as "mutualists", meaning those who value the environment for its own sake, and "utilitarians," meaning those who value the environment for the services it can provide. We surveyed 71 California winegrape growers in order to better understand how their underlying environmental values relate to the use of barn owl boxes and other sustainable practices. Overall, most winegrape growers had mutualist value orientations (64\%). However, there was a disconnect between the use of barn owl boxes and EVOs, with most respondents $(80 \%)$ reporting the use of owl boxes regardless of underlying values. This opens the door for future research to examine whether this is true of other wildlife-friendly farming practices.

Key words: barn owl boxes, California, environmental values, integrated pest management, sustainable farming, vineyards, winegrapes

Addressing agricultural impacts to biodiversity demands that environmental scientists investigate sustainable farming practices (Godfray et al. 2010), including the use of integrated pest management (IPM). The principles of IPM involve creating management plans that 
first rely on natural means, such as leveraging natural pest enemies, to control pests before turning to synthetic pesticides if necessary (Gray et al. 2009). The principles of IPM are gaining broad popularity across agriculture, and winegrape growing has been particularly successful at promoting IPM at an institutional level (Viers et al. 2013; Winkler et al. 2017).

California is the nation's most profitable agricultural state, and its most valuable crop is grapes, valued at $\$ 6.25$ billion annually (CDFA 2018). Winegrape cultivation is a highly visible and economically important industry for the state (Dyer 2015), but winegrapes are particularly vulnerable to vertebrate pests, especially rodents (Gebhardt et al. 2011). Administration of toxic baits is a common conventional method employed to reduce rodent pest populations in agriculture (Tickes et al. 1982; Wood and Fee 2003). However, the use of rodenticides, including second-generation anticoagulant rodenticides (SGARs), poses serious risks to non-target wildlife, raising ethical concerns (Kross et al. 2019). Though SGARs are not permitted at field scales in winegrape vineyards, public concern is strong and winegrape growers have begun to pursue alternative approaches as part of IPM solutions in an effort to improve their public image and enhance economic and environmental sustainability (Gray et al. 2009). Among these alternatives is the use of nest boxes for barn owls (Tyto furcata and T. alba; Labuschagne et al. 2016), which has been practiced in commodity and forage crops such as maize (Ojwang and Oguge 2003) and alfalfa (Motro 2011), as well as luxury crops such as date palms (Meyrom et al. 2009) and winegrapes (Johnson et al. 2018). Although confirmation of whether barn owl nest boxes can meaningfully reduce rodent numbers in winegrape vineyards awaits experimentation, recent work showed they can help control rodent pests in Spain (Paz Luna et al. 2020). Empirical fieldwork in California showed they can remove large numbers of rodents from vineyard landscapes (Johnson and St. George 2020), and modeling suggests they may be able to help control gophers (Kross and Baldwin 2016) and other rodents (Meyrom et al. 2009; Hiroyasu et al. 2019) when their densities are not especially high.

There is little information about how winegrape growers have responded to the use of barn owl nest boxes, and how they may change their pest management practices to be more sustainable in the future (Kross et al. 2017). Wine consumers have demonstrated a willingness to pay more for products perceived as being environmentally friendly (Sellers-Rubio and Nicolau-Gonzalbez 2016; Schäufele and Hamm 2017) and profitability can influence producers' adoption of environmentally sustainable practices (Marshall et al. 2005). However, recent studies are finding more complex cognitive motivations for pro-environmental choices (Sulemana and James 2014; Thompson et al. 2015; Floress et al. 2017), with many researchers studying wildlife and environmental value orientations (Jacobs et al. 2014) that take into account psychosocial variables that acknowledge the complexity of human decision making. One such framework is the values-attitudes-behavior cognitive hierarchy (Cook and Ma 2014; Floress et al. 2017). In this approach, values are the most basic, fundamental beliefs, and norms by which individuals evaluate how desirable they find a given action or outcome (Fulton et al. 1996; Cook and Ma 2014). These values are the basis upon which attitudes are formed and attitudes then influence behavior. There is no perfect predictor of behavior, but there is evidence suggesting that understanding an individual's core values is critical for forecasting and potentially influencing their decision making (Ajzen and Fishbein 1977; Honig et al. 2015). This makes values research potentially powerful in efforts to increase sustainable practices.

In this study we assessed why California winegrape growers choose to engage in sustainable farming by parsing out the associations between environmental values and a 
number of sustainable practices, including the use of barn owl boxes. Grounded in a wildlife value orientation (WVO) and cognitive hierarchy framework (Fulton et al. 1996), our study builds on the preliminary survey distributed by Wendt and Johnson (2017) in Napa Valley. Within the WVO literature, individuals are scored on their tendencies toward mutualism, placing intrinsic value on wildlife, and domination, prioritizing human needs over those of wildlife. They are then placed on a spectrum from mutualist, those who value wildlife for its own sake, to utilitarian, those who value wildlife as a service for human benefit (Fulton et al. 1996). We adapted this approach to more broadly apply to the natural environment.

We aimed to address three key areas for winegrape growers: environmental values, farming practices, and the association between the two. Specifically, we wanted to explore how winegrape growers' survey responses reflect mutualist or utilitarian values toward wildlife and the environment. We also sought to document which rodent pest control methods winegrape growers currently use and what sources of information they trust for pest control. Among respondents who use owl boxes for pest control, we examined how effective they feel nest boxes are at controlling rodents and how they see owls affecting their farms overall. Finally, we investigated what factors associate with winegrape growers use of more environmentally friendly practices and to what degree their behaviors align with utilitarian or mutualistic value orientations.

\section{METHODS}

\section{Survey}

Our survey was built around a modified version of the instrument developed by Fulton et al. (1996). For the values portion, respondents were presented with 20 statements and asked to evaluate the extent to which they agreed or disagreed with them based on a 7-point Likert scale from strongly disagree (1) to strongly agree (7).

These statements were intended to measure five wildlife and environmental belief dimensions: (1) wildlife rights, (2) wildlife use, (3) wildlife appreciation, (4) environmental protection concerns, and (5) willingness to use environmentally friendly farming techniques (see Table 1 for the list of questions and their alignment with these five dimensions). These five measures were then combined to measure two EVOs, (1) domination and (2) mutualism; see Table 1 for statement sorting. In this context, those with a domination value orientation are more likely to prioritize human well-being over the environment and welfare of wildlife, and they are more likely to find environmentally damaging behaviors to be acceptable if they serve a utilitarian purpose. Those with a mutualist value orientation are more likely to empathize with wildlife, find intrinsic value in the environment, and oppose environmentally damaging behaviors (Brodt et al. 2006; Teel and Manfredo 2010). The items in this instrument were adapted from similar surveys by Brodt et al. (2006), Fulton et al. (1996), Teel and Manfredo (2010), Thompson et al. (2015), and Whittaker et al. (2006). Most of the items for the belief dimensions involving environmental protection and farming practices were adapted from Brodt et al. (2006), modified to address agriculture-specific issues in place of the more residential or personal statements included in strictly wildlife-focused studies like Fulton et al. (1996) (see Estes 2019 for a complete breakdown of statement sources).

In addition to the questions aimed at environmental values, the survey included questions intended to document respondents' actions and perceptions relating to the use of barn owl boxes. The survey also included some basic demographic questions about respondents 
Table 1. Confirmatory factor analysis (CFA) and reliability scores for items used to measure wildlife and environmental value orientations from a 2018 survey of California winegrape growers.

\begin{tabular}{|c|c|c|}
\hline $\begin{array}{l}\text { Wildlife/Environmental Value Orientations, } \\
\text { Basic Belief Dimensions, and Scale Items }{ }^{\mathrm{a}}\end{array}$ & $\begin{array}{l}\text { Factor } \\
\text { Loading }\end{array}$ & $\begin{array}{l}\text { F's } \\
\text { alpha }\end{array}$ \\
\hline Domination value orientation ( $2^{\text {nd }}$ order factor $)$ & & 0.88 \\
\hline Wildlife Rights belief dimension ( $1^{\text {st }}$ order factor $)$ & 0.769 & 0.89 \\
\hline The needs of humans should take priority over fish and wildlife protection & 0.882 & \\
\hline $\begin{array}{l}\text { Although wildlife may have certain rights, most human needs are more im- } \\
\text { portant than the rights of wildlife }\end{array}$ & 0.896 & \\
\hline $\begin{array}{l}\text { The needs of people are always more important than any rights that wildlife } \\
\text { may have }\end{array}$ & 0.814 & \\
\hline The rights of people and the rights of wildlife are equally important ${ }^{c}$ & 0.714 & \\
\hline Wildlife Use belief dimension ( $1^{\text {st }}$ order factor) & $1.057^{\mathrm{d}}$ & 0.71 \\
\hline Humans should manage fish and wildlife populations so that humans benefit & 0.634 & \\
\hline $\begin{array}{l}\text { It is acceptable for people to kill wildlife if they think it poses a threat to their } \\
\text { life }\end{array}$ & 0.683 & \\
\hline $\begin{array}{l}\text { It is acceptable for people to kill wildlife if they think it poses a threat to their } \\
\text { property }\end{array}$ & 0.801 & \\
\hline $\begin{array}{l}\text { We should strive for a world where there is an abundance of fish and wildlife } \\
\text { for hunting and fishing }\end{array}$ & 0.415 & \\
\hline Mutualism value orientation ( $2^{\text {nd }}$ order factor) & & 0.87 \\
\hline Wildlife Appreciation belief dimension ( $1^{\text {st }}$ order factor $)$ & 0.657 & 0.91 \\
\hline Wildlife is an important part of my community & 0.914 & \\
\hline I'm interested in making the area around my farm attractive to wildlife & 0.943 & \\
\hline Having wildlife around my farm is important to me & 0.963 & \\
\hline Environmental Protection belief dimension $\left(1^{\text {st }}\right.$ order factor $)$ & $1.012^{\mathrm{d}}$ & 0.76 \\
\hline I want to increase biodiversity on my farm even if it takes land out of production & 0.732 & \\
\hline I strive to learn how to manage resources in cooperation with nature & 0.519 & \\
\hline $\begin{array}{l}\text { The environmental value of my farm is just as important as its agricultural } \\
\text { value }\end{array}$ & 0.641 & \\
\hline It is important to maintain biodiversity for future generations & 0.834 & \\
\hline Farming Practices belief dimension $\left(1^{\text {st }}\right.$ order factor $)$ & 0.89 & 0.75 \\
\hline $\begin{array}{l}\text { I consider a decrease in pesticide use one way to improve living and working } \\
\text { conditions on my farm }\end{array}$ & 0.763 & \\
\hline I use whatever fertilizers and pesticides are necessary to get the job done ${ }^{c}$ & 0.635 & \\
\hline $\begin{array}{l}\text { I am not willing to sacrifice farm profitability to conserve water or other } \\
\text { resources }^{c}\end{array}$ & 0.454 & \\
\hline $\begin{array}{l}\text { I cannot see using environmentally friendly management techniques if they } \\
\text { sacrifice yield or crop quality }\end{array}$ & 0.631 & \\
\hline
\end{tabular}

${ }^{\text {a }}$ Item response scale: 1 (strongly disagree) to 7 (strongly agree).

${ }^{\mathrm{b}}$ Standardized factor loadings from CFA. Fit statistics: $\chi^{2}=223.41(\mathrm{df}=146 ; \mathrm{p}<0.001)$; CFI $=0.90$; GFI

$=0.77 ;$ RMSEA $=0.08 ;$ SRMR $=0.08$.

${ }^{\mathrm{C}}$ Item was reverse coded prior to analysis.

${ }^{d}$ Factor loadings greater than 1 likely reflect high multicollinearity (Jöreskog 1999). 
(e.g. age, gender) and their property (e.g. acreage), and Likert scale questions about pest species, rodent control methods, farming techniques (organic, biodynamic, conventional, etc.), and levels of trust in different sources of pest control information (e.g. personal observation, research groups, peers). The full survey instrument can be found in Estes 2019.

\section{Data Collection}

All data collection was done in compliance with federal regulations on the use of human subjects and was approved by Humboldt State University's Institutional Review Board (IRB 16-231). Surveys were administered electronically via SurveyGizmo to California winegrape growers by contacting wine industry groups, starting with the Napa Valley Grapegrowers (NVG) and the statewide California Association of Winegrape Growers (CAWG), but this garnered relatively few responses. A more targeted effort was made to reach out to American Viticultural Area (AVA) associations and smaller sub-appellation groups, starting with those in Napa and expanding to all AVAs with an association for which contact information was available. In all, 35 groups were emailed, and the survey was distributed to the members of 14 groups, including the NVG (see Estes 2019 for a full list of participating groups). A small number of surveys were also obtained after emailing some vineyards directly, but the majority of responses came from members of smaller appellation and sub-appellation groups who were emailed a link to the survey. In total, 71 surveys were completed. Respondents must have finished at least the values questions to be considered complete as these questions formed to core of all subsequent analyses.

\section{Data Analysis}

This survey was conducted to obtain preliminary data from wine producers and inform future research. As such, an inductive approach was used, with numerous exploratory analyses to compare the attitudes of participating growers with existing wildlife and environmental values literature. There were 20 values statements in the survey, one of which, regarding wildlife suffering, was discarded for analysis due to poor fit with any models (see Estes 2019 for a complete list of items). Following the method pioneered in Fulton et al. (1996), the remaining 19 items were put through a two-stage confirmatory factor analysis (CFA) in AMOS (Arbuckle 2019) to test for internal consistency and goodness of fit. The first order analysis sorted statements into one of five factors corresponding to basic belief dimensions about (1) wildlife rights, (2) wildlife use, (3) wildlife appreciation, (4) environmental protection, and (5) farming techniques. These were then run through another CFA to separate these factors into two second-order factors corresponding to domination (factors 1 and 2) and mutualistic (factors 3-5) value orientations. These second order factor models had a chi-square of $223.41(\mathrm{df}=146 ; \mathrm{P}<0.001)$. Several analyses were used to assess goodness of fit, $\mathrm{CFI}=0.90, \mathrm{GFI}=0.77, \mathrm{RMSEA}=0.08, \mathrm{SRMR}=0.08$, and while most did not reach suggested thresholds (CFI $\geq .95, \mathrm{GFI} \geq 0.90, \mathrm{RMSEA}$ and $\mathrm{SRMS} \leq 0.08$; Hooper et al. 2008; Kline 2011) likely due to the small sample size, the models were not discarded as this is an exploratory study. While useful, these fit indices are biased toward large sample sizes and there is evidence that they may not generalize well outside the narrow set of models from which they were developed (Barrett 2007; Kline 2011). Reliability analyses were also run in SPSS (IBM Corp 2017), and they indicated high inter-item consistency with Cronbach's alpha scores between 0.71 and 0.95 (see Table 1; Nunnally and Bernstein 1994). 
Once values items were sorted by factor, an average for each first order factor belief dimension (e.g., wildlife appreciation) was calculated for each participant by averaging the corresponding Likert-scale responses. Then, the second order value orientations were calculated by taking the means of the corresponding belief dimension items. Based on these scores, respondents were then sorted into four groups by adapting the method used by Teel et al. (2005). Value orientation (second order factor) scores above 4.5 (out of 7) were considered "high" and less than or equal to 4.5 were considered "low." Participants who scored high on domination and low on mutualism were classified as "utilitarians," those who scored low on domination and high on mutualism were classified as "mutualists," those who scored high on both were classified as "pluralists," and those scoring low on both "distanced."

In subsequent analyses, the distanced category was excluded because only three respondents were classified into this group, and the utilitarian and pluralist groups were combined to facilitate substantive analyses because each group was small, 10 and 13 respondents respectively. This combined group then represented the 23 respondents that had a high domination score to compare to the mutualist group of 45 respondents with low domination scores. These two broad groups of respondents (low domination scores vs. high domination scores) were then used as independent variables in cross-tabulations for categorical response variables, and in independent samples $t$-tests for scaler response variables, to assess the differences in responses to other survey questions, such as percent non-crop habitat and use of pest control techniques. Binary responses, such as those who do and do not use owl boxes, were also used as independent variables to compare participants' domination and mutualism scores. See Estes 2019 for full survey instrument and variable breakdown.

\section{RESULTS}

There were 113 surveys submitted, of these 71 were complete and included in analyses. As the surveys were distributed by local and regional organizations to maintain their members' anonymity, a precise response rate cannot be calculated; however, it was likely less than 5\% because the organizations' collective email distribution lists exceeded 2,000 recipients. Napa County was the most heavily represented, with $43.7 \%(n=31)$ of respondents, the rest being spread across 10 other counties (Fig. 1). Of the respondents included in the analyses, $77.5 \%$ self-identified as male $(\mathrm{n}=55)$ and $18.3 \%$ as female $(\mathrm{n}=13) ; 64$ respondents provided their age, of these the average age was $56(\mathrm{SD}=12.54)$. A majority of respondents identified their role as owner/operator $(87 \%, n=62)$ with the remainder identifying as either part of a management company, a winemaker, or staff. The vineyards addressed in the survey were also mostly small, with $91.5 \%(n=65)$ being 200 acres or less (Fig. 2).

In response to a question about reliability of various sources of information on pest management strategies on a scale of 1 (very unreliable) to 5 (very reliable), respondents found personal observation to be the most reliable $(\mathrm{M}=4.04, \mathrm{SD}=0.98)$, followed by research groups $(\mathrm{M}=3.90, \mathrm{SD}=0.97)$, and meetings or workshops $(\mathrm{M}=3.64, \mathrm{SD}=0.99)$. Respondents found owl box experts $(\mathrm{M}=2.79, \mathrm{SD}=0.86)$ and social media $(\mathrm{M}=2.81, \mathrm{SD}$ $=1.17$ ) to be the least reliable, however, all other sources averaged above neutral (Fig. 3).

\section{Value Orientations and Belief Dimensions}

Over $80 \%$ of the 71 respondents scored high $(>4.5)$ on the mutualism axis, whereas $32 \%$ scored high $(>4.5)$ on the domination axis. Based on these scores, $14.1 \%$ of respondents 


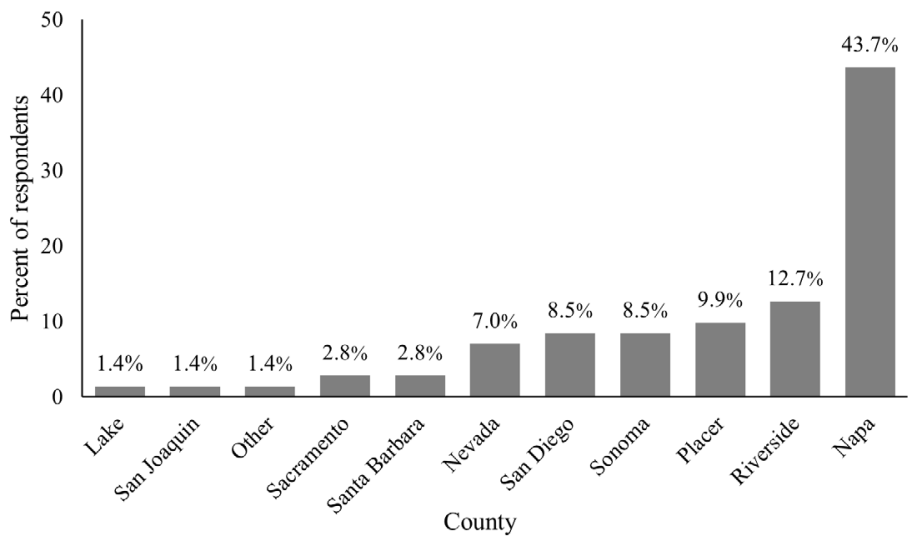

Figure 1. Percent of responses to a 2018 survey of California winegrape growers by county.

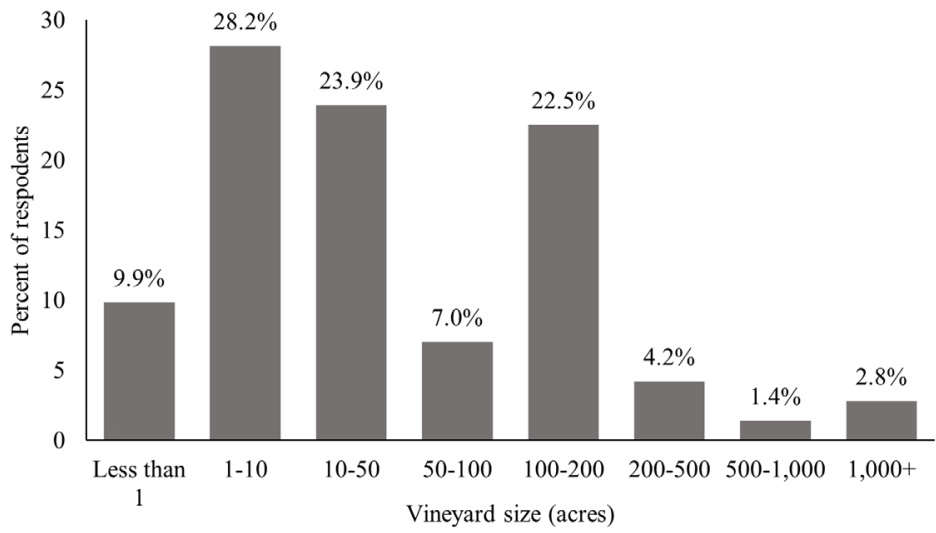

Figure 2. Frequency histogram of participant reported vineyard sizes from a 2018 survey of California winegrape growers.

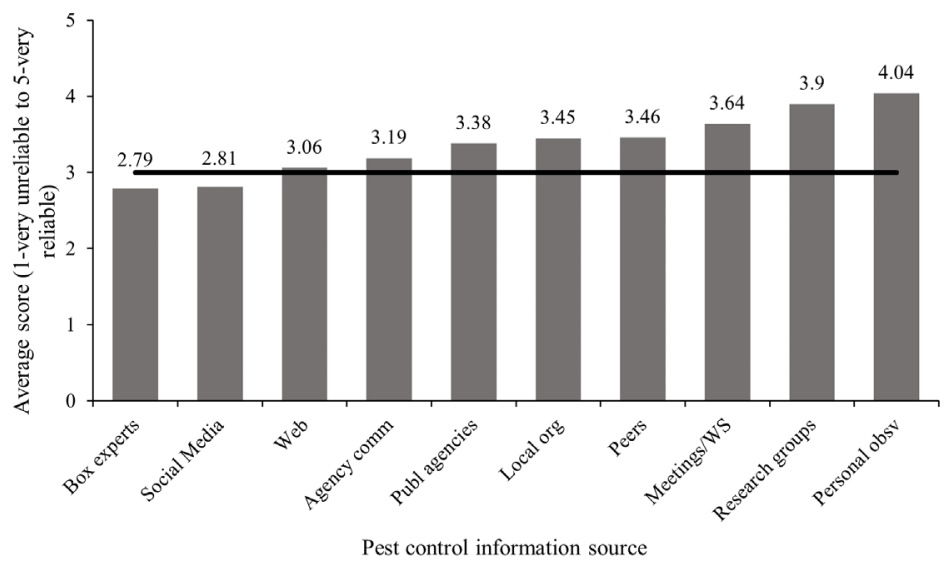

Figure 3. Average perceived reliability of pest control information sources from 1-very unreliable to 5-very reliable, from a 2018 survey of California winegrape growers. Horizontal line indicates an average score of 3-neutral. 
were classified as utilitarian (high domination low mutualism), 18.3\% as pluralists (high on both), $4.2 \%$ as distanced (low on both), and $63.4 \%$ as mutualists (high mutualism low domination; see Table 2). Additional descriptive statistics for utilitarians and pluralists can be found in Estes (2019, pg 114).

Table 2. Scoring of wildlife and environmental value orientation types based on value orientation scales and belief dimensions from a 2018 survey or California winegrape growers, adapted from Teel and Manfredo (2010).

\begin{tabular}{lcccccccc}
\hline $\begin{array}{l}\text { Value orientation and } \\
\text { belief dimension }\end{array}$ & \multicolumn{2}{c}{$\begin{array}{c}\text { Utilitarian } \\
(\mathrm{n}=10,14.1 \%)\end{array}$} & \multicolumn{2}{c}{$\begin{array}{c}\text { Pluralist } \\
(\mathrm{n}=13,18.3 \%)\end{array}$} & \multicolumn{2}{c}{$\begin{array}{c}\text { Mutualist } \\
(\mathrm{n}=45,63.4 \%)\end{array}$} & \multicolumn{2}{c}{$\begin{array}{c}\text { Distanced } \\
(\mathrm{n}=3,4.2 \%)\end{array}$} \\
& Mean & $\mathrm{SD}$ & Mean & $\mathrm{SD}$ & Mean & SD & Mean & SD \\
\hline Domination & 5.54 & 0.67 & 5.60 & 0.65 & 3.48 & 0.76 & 4.13 & 0.13 \\
$\quad$ Human priority & 5.30 & 1.00 & 5.29 & 1.04 & 2.61 & 0.90 & 3.50 & 0.43 \\
$\quad$ Wildlife use & 5.78 & 0.49 & 5.90 & 0.55 & 4.35 & 1.00 & 4.75 & 0.50 \\
Mutualism & 3.80 & 1.16 & 5.47 & 0.69 & 5.93 & 0.64 & 4.39 & 0.10 \\
$\quad$ Wildlife appreciation & 4.16 & 0.24 & 5.85 & 0.81 & 6.21 & 0.92 & 5.00 & 0.00 \\
$\quad \begin{array}{l}\text { Environmental protec- } \\
\text { tion concerns }\end{array}$ & 4.58 & 0.67 & 5.27 & 0.87 & 5.96 & 0.74 & 4.17 & 0.29 \\
$\quad$ Farming techniques & 4.10 & 0.92 & 5.29 & 0.90 & 5.56 & 0.98 & 4.00 & 0.00 \\
\hline
\end{tabular}

Several significant differences emerged between the mutualist and utilitarian/pluralist groups (Table 3). Mutualists tended to be younger and they reported a higher percentage of non-crop habitat on their farms. There was a comparatively higher proportion of mutualist females compared to males, however this difference was not statistically significant, possibly due to the overall male skew of respondents. There was also no statistically significant difference in farm size between mutualists and utilitarians/pluralists, though the former tended to have somewhat smaller farms (Table 3).

About half of respondents, $50.7 \%(\mathrm{n}=36)$, reported having at least one environmentally friendly certification, with Fish Friendly Farming being the most common at 29.6\% (n $=21$ ). However, this does not necessarily reflect how respondents were actually farming. For example, only $8.5 \%(n=6)$ of respondents were certified organic by the United States Department of Agriculture (USDA) or California Department of Food and Agriculture (CDFA), but $26.8 \%(n=19)$ reported using organic techniques. Similarly, only $4.2 \%(n=$ 3) reported being certified biodynamic, but $11.3 \%(n=8)$ reported using biodynamic techniques. There were also 14 respondents $(19.7 \%)$ who wrote in "sustainable" as the "other" option for techniques, while only $11.3 \%(\mathrm{n}=8)$ reported being certified sustainable by the California Sustainable Winegrowing Alliance (CSWA; Figs. 4 and 5).

Mutualists were more likely to have at least one certification and were more likely to use non-conventional techniques (organic, biodynamic, or sustainable) than utilitarian/ pluralists (Table 3). The proportion of respondents attracting birds as a pest control technique and using owl boxes specifically were similar between mutualists and utilitarian/pluralists (Table 3). Utilitarians were somewhat more likely to use rodenticides than mutualists, but this difference was statistically marginal (Table 3 ). 
Table 3. Comparison of wildlife and environmental value orientation types, participant demographics, and selected responses from a 2018 survey of California winegrape growers.

\begin{tabular}{|c|c|c|c|c|c|}
\hline Variable & $\begin{array}{l}\text { Utilitarian } \\
\text { or Pluralist }\end{array}$ & Mutualist & $\chi^{2}$ or $F(d f)^{a}$ & $\mathrm{P}$ & $\mathrm{ES}^{\mathrm{b}}$ \\
\hline Age $(\bar{\chi})$ & 61.05 & 54.02 & $4.8(1,61)$ & $0.03 *$ & \\
\hline Percent Non-crop Habitat $(\bar{\chi})$ & 24.83 & 44.9 & $6.67(1,65)$ & $0.01 *$ & \\
\hline Gender (\%) & & & $3.79(2)$ & 0.15 & 0.24 \\
\hline Female & 8.7 & 24.4 & & & \\
\hline Male & 91.3 & 71.1 & & & \\
\hline Farm Size in Acres (\%) & & & $12.93(7)$ & 0.074 & 0.44 \\
\hline Less than 1 & 13 & 8.9 & & & \\
\hline $1-10$ & 47.8 & 20 & & & \\
\hline $10-50$ & 17.4 & 22.2 & & & \\
\hline $50-100$ & 8.7 & 6.7 & & & \\
\hline $100-200$ & 4.3 & 33.3 & & & \\
\hline $200-500$ & 4.3 & 4.4 & & & \\
\hline $500-1,000$ & 4.3 & 0 & & & \\
\hline $1,000+$ & 0 & 4.4 & & & \\
\hline At least one certification (\%) & & & $7.95(1)$ & $0.005^{*}$ & 0.34 \\
\hline Yes & 26.1 & 62.2 & & & \\
\hline No & 73.9 & 37.8 & & & \\
\hline $\begin{array}{l}\text { Uses non-conventional tech- } \\
\text { niques }(\%)\end{array}$ & & & $0.46(1)$ & $0.032^{*}$ & 0.26 \\
\hline Yes & 34.8 & 62.2 & & & \\
\hline No & 65.2 & 37.8 & & & \\
\hline $\begin{array}{l}\text { Attract birds for pest manage- } \\
\text { ment }(\%)\end{array}$ & & & $0.44(1)$ & 0.507 & \\
\hline Yes & 82.6 & 75.6 & & & \\
\hline No & 17.4 & 24.4 & & & \\
\hline Owl Box (\%) & & & $0.51(1)$ & 0.477 & \\
\hline Yes & 87 & 80 & & & \\
\hline No & 13 & 20 & & & \\
\hline Uses Rodenticides (\%) & & & $3.27(1)$ & 0.07 & 0.22 \\
\hline Yes & 34.8 & 15.6 & & & \\
\hline No & 65.2 & 84.4 & & & \\
\hline
\end{tabular}

a Values from chi-squared or independent samples t-tests (two-tailed) with degrees of freedom.

${ }^{\mathrm{b}}$ Effect sizes. Cramer's V was used for chi-squared analyses. 


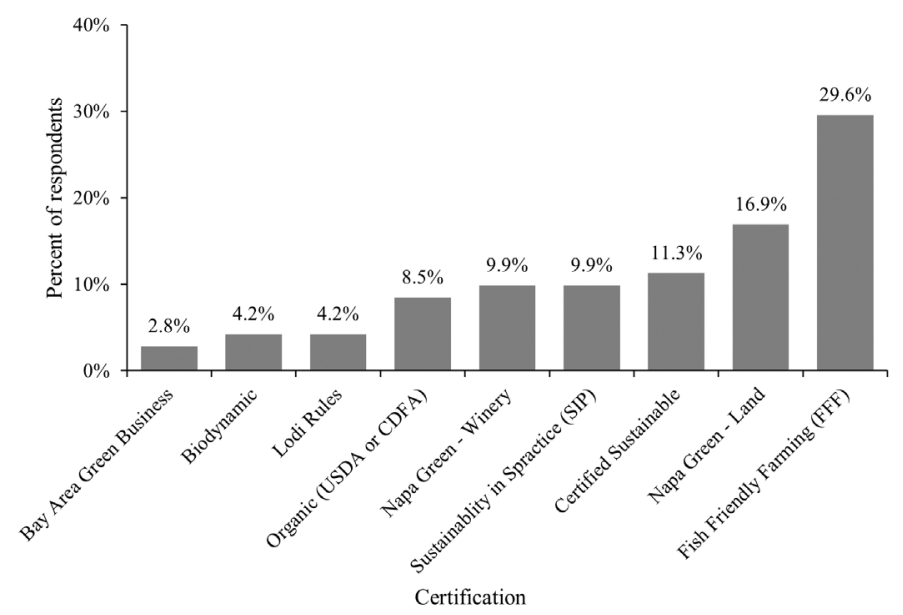

Figure 4. Percent of respondents with each environmental certification from a 2018 survey of California winegrape growers.

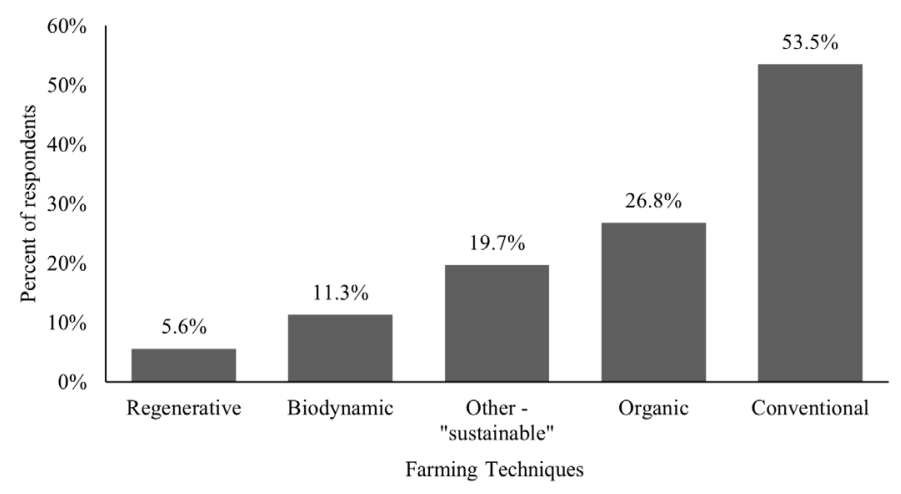

Figure 5. Percent of respondents to a 2018 survey of California winegrape growers who reported using different farming techniques. Other - "sustainable" refers to a write-in option.

\section{Barn Owl Boxes}

On a scale of 1 (not concerned) to 4 (very concerned), respondents were most concerned about rodent and insect pests, with an average response of $3.04(\mathrm{SD}=0.96)$ and $3.0(\mathrm{SD}=$ $0.92)$ respectively. When asked about rodent pest control techniques the most respondents reported attracting birds, $77.5 \%(\mathrm{n}=55)$, followed by $52.1 \%(\mathrm{n}=37)$ who used rodent kill traps and $21.1 \%(\mathrm{n}=15)$ who used rodenticides. A majority of respondents also reported using barn owl boxes specifically $(81.7 \%, \mathrm{n}=58)$, which limited capacity to statistically compare responses to other questions by those who did and did not use boxes. While the overall use of rodenticides was low, all but one of these respondents also reported using owl boxes. Of those using boxes, $13.5 \%(\mathrm{n}=8)$ also reported using some form of chemical rodenticide.

In response to the question on the effects of owl boxes on a scale of 1 (very harmful) to 5 (very beneficial), respondents on average rated them positively on five metrics. The effect on rodent pests scored the highest $(\mathrm{M}=4.25, \mathrm{SD}=0.99)$, followed by tourism $(\mathrm{M}$ $=3.93, \mathrm{SD}=1.78)$, vine health $(\mathrm{M}=3.47, \mathrm{SD}=0.66)$, grape yield $(\mathrm{M}=3.32, \mathrm{SD}=0.60)$, and bird pests $(\mathrm{M}=3.12, \mathrm{SD}=0.47)$. 
Associations between respondents' value orientations (second order factor scores) and use of barn owl boxes were mixed. On average respondents who used owl boxes had a higher domination and lower mutualism score than those who did not, but the differences were not statistically significant (Fig. 6). Differences in average value orientation scores were statistically significant between those who did and did not use rodenticides, with those using rodenticides having higher domination and lower mutualism scores than those who did not (Fig. 6). Average value orientation scores also differed significantly based on certifications and sustainable technique use. Participants with at least one certification had a lower domination and higher mutualism score on average than those without; and participants who reported using sustainable techniques also had a lower domination and higher average mutualism score than those who did not (Fig. 6).

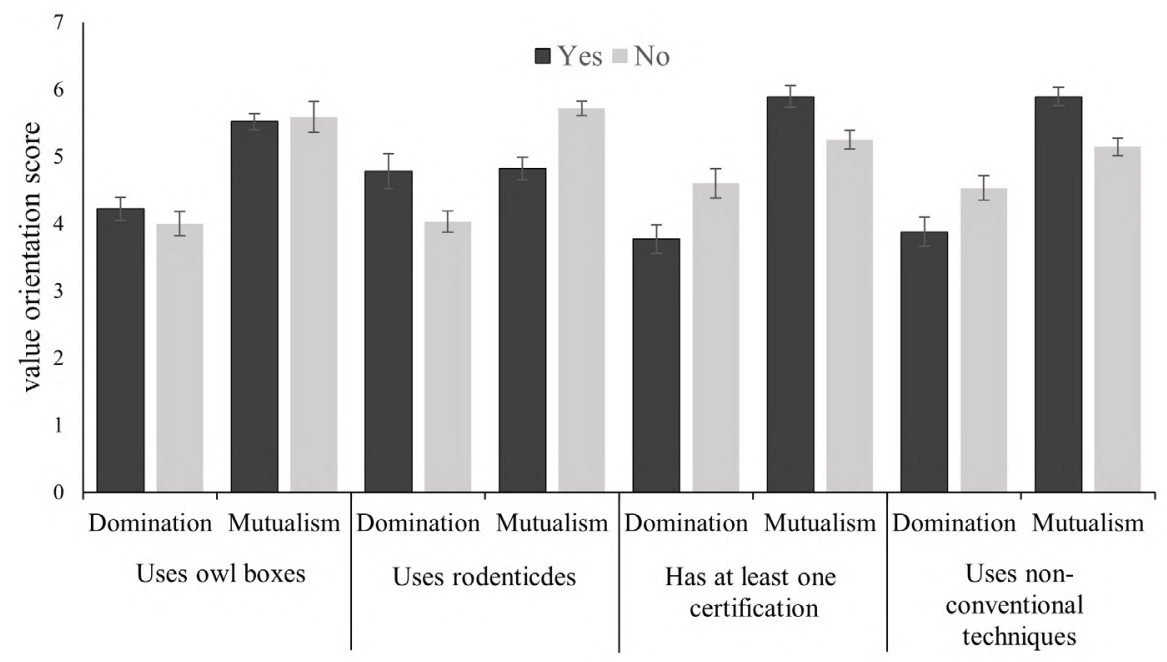

Figure 6. Average second-order factor value orientation scores (domination and mutualism) compared with standard error bars for the use of owl boxes, rodenticides, environmental certifications, and non-conventional techniques by California winegrape growers in 2018 .

\section{DISCUSSION}

A better understanding of farmers' underlying values and how they relate to the use of environmentally friendly practices could inform outreach polices to help encourage their adoption (Brodt et al. 2006; Sulemana and James 2014). Analyses in this paper suggest that most winegrape growers surveyed tend more toward mutualist environmental values (high mutualist and low domination scores, 63\% of respondents), than toward utilitarian values (high domination and low mutualism scores, $14 \%$ of respondents), or to pluralist values (both high utilitarian and mutualism scores, $18 \%$ of respondents). The proportion of respondents in this study that aligned with mutualist values is higher than most WVO research has found in the past. For example, in a 2005 survey of 7,388 respondents from 19 western states, only $35 \%$ were classified as mutualists, with $28 \%$ classified as utilitarians (called "traditionalists"), 21\% as pluralists, and 15\% as distanced (Manfredo et al. 2018). The higher proportion of mutualists among winegrape growers suggest they may be particularly receptive to considering adoption of environmentally friendly practices. 


\section{Grape-grower Use of Barn Owl Boxes and Other Non-conventional Techniques}

Reported use of non-conventional farming techniques was high, with $53.5 \%(\mathrm{n}=38)$ of respondents indicating the use of at least one non-conventional farming technique. Direct comparisons with other data are not available, but it is reasonable to conclude that the winegrape growers in this study fall above the average for agricultural producers in general. For example, in this study $8.5 \%$ of respondents reported being USDA or CDFA certified organic, whereas less than $0.01 \%$ of farms nationally and $0.04 \%$ of farms in California were certified organic in 2016 (NASS 2017).

There is some ambiguity in these results, however, as the responses for various sustainable techniques did not align with certifications. For example, $23 \%$ of respondents $(n=16)$ indicated they used some kind of sustainable techniques but did not have any certifications. Conversely, $20 \%$ of respondents $(n=14)$ reported having at least one certification but did not indicate the use of any sustainable farming techniques. This particular discrepancy may be due to the fact that some certifications listed do not necessarily focus specifically on crop production (e.g. soil erosion, irrigation, habitat restoration, etc.). This is potentially important when considering how the perception of some environmentally friendly techniques may increasingly be somewhat divorced from their "sustainable" connotations.

It is striking that the most frequently reported strategy was attracting birds, at $77.5 \%$ $(\mathrm{n}=55)$ and an overwhelming $82 \%(\mathrm{n}=58)$ of respondents reported using barn owl boxes specifically. The difference between these is due to six participants who indicated they used owl boxes but did not indicate that they attract birds to their property for rodent control.

Reported rodenticide use was low, at $21 \%(\mathrm{n}=15)$, but nearly all of these respondents also reported using barn owl boxes. This is potentially concerning as the primary strategy for deploying rodenticides is via bait stations, which allow rodents to disperse after consumption to potentially be predated by barn owls and other predators. In California, at the time of this survey, four common SGARs were classified as restricted materials that may only be applied by professionals with permits issued by a county commissioner (CDPR 2017), with a newly signed bill (AB 1788) introducing additional restrictions (Bloom et al. 2020).

There are also numerous other factors that are not taken into account by this survey; for example, grapegrowers may be using rodenticides only during non-breeding seasons when owl populations are much lower, in fields that are netted to keep out smaller bird pests, or they may be compensating for a decline in box occupancy, all of which would at least reduce the risk of exposure. Qualitative research is needed to clarify the issue and discern how aware these grapegrowers are of the potential hazards of overlapping rodenticides (Kross et al. 2019).

\section{Associations between Barn Owl Box Use and Value Orientations}

Examining the associations between respondents' value orientations (second order factors) suggests that while some behaviors did differ between mutualists and utilitarian/ pluralists, the use of barn owl boxes was widespread among all participants. For example, there were strong differences in the proportion of mutualists and others in their reported use of non-conventional practices and some form of certification, but the use of barn owl boxes was over $80 \%$ regardless of respondents' value orientation (Fig. 6). This was a surprising result, and several lines of evidence suggest this result may reflect a normalization of the use barn owl boxes. Indeed, similar percentages of mutualists and utilitarian/pluralists used 
barn owl boxes, and the domination and mutualism scores for those who did and did not use owl boxes were not significantly different.

The lack of association between barn owl box use and EVOs may relate, at least in part, to the values-attitudes-behavior cognitive hierarchy. This approach asserts that values are the most fundamental, least changeable part of an individuals' cognitive foundation; they are the basis for decision making and are embedded not only within the individual, but within families, groups, and society at large. As discussed by Manfredo et al. (2017), this makes it impractical to focus on trying to change values to reach conservation goals. While it is useful and important to understand how values influence behavior, changes in values happen slowly and are only minimally influenced by behavioral changes. Manfredo et al. (2017) suggest focusing instead higher up on the cognitive hierarchy; on attitudes, behaviors, and norms. This may be where owl boxes fit in.

There are likely mutualist winegrape growers who use owl boxes because they are in-line with their core values, but there must be other influences that can account for the high degree of adoption across the board. For example, Wendt and Johnson (2017) found that many grapegrowers believe the nest boxes help decrease pest problems, and evidence is accumulating to suggest that their use may reduce rodent numbers in fields (Kross and Baldwin 2016; Johnson and St. George 2020). Thus, the value of the pest control services provided by barn owls appears widely recognized among winegrape growers. Moreover, there is a low barrier to entry for this practice. Owl boxes are relatively cheap and easy to install with little oversight as there is no monitoring or recording that needs to be reported to regulators. Owl boxes also count toward many certifications that may allow growers to charge more for their products or attract more eco-minded consumers. Taken together, the increasing recognition of the practical value of owl boxes coupled with other benefits and a low barrier to entry may have encouraged their use well beyond those who may have initially adopted the practice out of principle and alignment with their core values.

\section{ACKNOWLEDGEMENTS}

We would like to thank all the viticultural associations that helped distribute our survey and all the winegrowers who participated. Special thanks to J. Putnam and M. Williams of Napa Valley Grapegrowers and N. Collins of the California Association of Winegrape Growers for their help developing the survey. Funding for this project was provided by the California State University Agricultural Research Initiative.

\section{LITERATURE CITED}

Ajzen, I., and M. Fishbein. 1977. Attitude-behavior relations: A theoretical analysis and review of empirical research. Psychological Bulletin 84:888-918.

Barrett, P. 2007. Structural equation modelling: Adjudging model fit. Personality and Individual Differences 42:815-824.

Bloom, R., L. Friedman, and H. Stern. 2020. Pesticides: use of second-generation anticoagulant rodenticides. Food and Agriculture Code.

Brodt, S., K. Klonsky, and L. Tourte. 2006. Farmer goals and management styles: Implications for advancing biologically based agriculture. Agricultural Systems 89:90105.

California Department of Food and Agriculture (CDFA). 2018. California Agricultural Statistics Review 2016-2017. 
California Department of Pesticide Regulation (CDPR). 2017. A Guide to Pesticide Regulation in California 2017 Update. California Environmental Protection Agency.

Cook, S. L., and Z. Ma. 2014. The interconnectedness between landowner knowledge, value, belief, attitude, and willingness to act: Policy implications for carbon sequestration on private rangelands. Journal of Environmental Management 134:90-99.

Dyer, S. 2015. Democratizing visions of luxury and the good life in California wine country: wine tourism from repeal to the eve of the "Wine Revolution." Business and Economic History | On-Line. Volume 13.

Estes, B. 2019. Environmental values of California winegrape growers and the use of barn owls (Tyto alba) as a tool for integrated pest management. Thesis, Humboldt State University, Arcata, CA, USA.

Floress, K., S. García de Jalón, S. P. Church, N. Babin, J. D. Ulrich-Schad, and L. S. Prokopy. 2017. Toward a theory of farmer conservation attitudes: dual interests and willingness to take action to protect water quality. Journal of Environmental Psychology 53:73-80.

Fulton, D. C., M. J. Manfredo, and J. Lipscomb. 1996. Wildlife value orientations: a conceptual and measurement approach. Human Dimensions of Wildlife 1:24-47.

Gebhardt, K., A. M. Anderson, K. N. Kirkpatrick, and S. A. Shwiff. 2011. A review and synthesis of bird and rodent damage estimates to select California crops. Crop Protection 30:1109-1116.

Gray, M. E., S. T. Ratcfliffe, and M. E. Rice. 2009. The IPM paradigm: concepts, strategies, and tactics. Pages 1-13 in E. B. Radcliffe, W. D. Hutchison, and R. E. Cancelado, editors. Integrated pest management: concepts, tactics, strategies and case studies. Cambridge University Press, New York, NY, USA.

Godfray, H. C. J., J. R. Beddington, I. R. Crute, L. Haddad, D. Lawrence, J. F. Muir, J. Pretty, S. Robinson, S. M. Thomas, and C. Toulmin. 2010. Food security: the challenge of feeding 9 billion people. Science 327:812-818.

Hiroyasu, E. H. T., S. M. Kross, B. E. Kendall, and R. A. Baldwin. 2019. Assessing the potential utility of barn owls as a biocontrol option against burrowing rodents in California. American Fisheries Society \& The Wildlife Society 2019 Joint Annual Conference, Reno, NV, USA.

Honig, M., S. Petersen, C. Shearing, L. Pintér, and I. Kotze. 2015. The conditions under which farmers are likely to adapt their behaviour: a case study of private land conservation in the Cape Winelands, South Africa. Land Use Policy 48:389-400.

Hooper, D., J. Coughlan, and M. Mullen. 2008. Structural equation modelling: guidelines for determining model fit. Electronic Journal of Business Research Methods 6:53-60.

Jacobs, M. H., J. J. Vaske, and M. T. J. Sijtsma. 2014. Predictive potential of wildlife value orientations for acceptability of management interventions. Journal for Nature Conservation 22:377-383.

Johnson, M. D., and D. S. St. George. 2020. Estimating the number of rodents removed by barn owls nesting in boxes on winegrape vineyards. Proceedings of the Vertebrate Pest Conference 29: Paper No. 17.

Johnson, M. D., C. A. Wendt, B. R. Estes, and X. A. Castañeda. 2018. Can barn owls help control rodents in winegrape vineyard landscapes? A review of key questions and suggested next steps. Proceedings of the Vertebrate Pest Conference 28:180-187. 
Jöreskog, K. G. 1999. How large can a standardized coefficient be? Available from: http:// www.statmodel.com/download/Joreskog.pdf (August 2019)

Kline, R. B. 2011. Principles and Practice of Structural Equation Modeling. 3rd edition. Methodology in the Social Sciences, The Guilford Press, New York, NY, USA.

Kross, S. M., and R. A. Baldwin. 2016. Gopherbusters? A review of the candidacy of barn owls as the ultimate natural pest control option. Proceedings of the Vertebrate Pest Conference 27:345-352.

Kross, S. M., E. H. T. Hiroyasu, R. Baldwin, B. Martinico, R. Bourbour, E. Phillips, and J. M. Hull. 2019. Vertebrate control from raptors motivates farmers to install nest boxes, but is secondary poisoning a concern? Ecological Society of America \& The United States Society for Ecological Economics Joint Meeting, Louisville, KY, USA.

Kross, S. M., K. P. Ingram, R. F. Long, and M. T. Niles. 2017. Farmer perceptions and behaviors related to wildlife and on-farm conservation actions. Conservation Letters 11(1):e12364.

Labuschagne, L., L. H. Swanepoel, P. J. Taylor, S. R. Belmain, and M. Keith. 2016. Are avian predators effective biological control agents for rodent pest management in agricultural systems? Biological Control 101:94-102.

Manfredo, M. J., J. T. Bruskotter, T. L. Teel, D. Fulton, S. H. Schwartz, R. Arlinghaus, S. Oishi, A. K. Uskul, K. Redford, S. Kitayama, and L. Sullivan. 2017. Why social values cannot be changed for the sake of conservation. Conservation Biology 31:772-780.

Manfredo, M. J., L. Sullivan, A. W. Don Carlos, A. M. Dietsch, T. L. Teel, A. D. Bright, and J. Bruskotter. 2018. America's wildlife values: the social context of wildlife management in the U.S. National report from the research project entitled "America's Wildlife Values," Colorado State University, Department of Human Dimensions of Natural Resources, National Report, Fort Collins, CO, USA.

Marshall, R. S., M. Cordano, and M. Silverman. 2005. Exploring individual and institutional drivers of proactive environmentalism in the U.S. Wine industry. Business Strategy and the Environment 14:92-109.

Meyrom, K., Y. Motro, Y. Leshem, S. Aviel, I. Izhaki, F. Argyle, and M. Charter. 2009. Nest-box use by the barn owl Tyto alba in a biological pest control program in the Beit She'an Valley, Israel. Ardea 97:463-467.

Motro, Y. 2011. Economic evaluation of biological rodent control using barn owls Tyto alba in alfalfa. European Vertebrate Pest Management Conference Book of Abstracts 8:79-80.

National Agricultural and Statistics Service (NASS). 2017. Certified Organic Survey, 2016 Summary. U.S. Department of Agriculture Report.

Nunnally, J. C., and I. H. Bernstein. 1994. Psychometric Thoery. 3rd edition. McGraw-Hill Series in Psychology, McGraw-Hill, New York, NY, USA.

Ojwang, D. O., and N. O. Oguge. 2003. Testing a biological control program for rodent management in a maize cropping system in Kenya. Aciar Monograph Series 96:251-253.

Paz Luna, A., H. Bintanel, J. Viñuela, and D. Villanúa. 2020. Nest-boxes for raptors as a biological control system of vole pests: high local success with moderate negative consequences for non-target species. Biological Control 146:104267. 
Schäufele, I., and U. Hamm. 2017. Consumers' perceptions, preferences and willingnessto-pay for wine with sustainability characteristics: a review. Journal of Cleaner Production 147:379-394.

Sellers-Rubio, R., and J. L. Nicolau-Gonzalbez. 2016. Estimating the willingness to pay for a sustainable wine using a Heckit model. Wine Economics and Policy 5:96-104.

Sulemana, I., and H. S. James. 2014. Farmer identity, ethical attitudes and environmental practices. Ecological Economics 98:49-61.

Teel, T., A. Dayer, M. Manfredo, and A. Bright. 2005. Regional results from the research project entitled "Wildlife Values in the West." Western Association of Fish and Wildlife Agencies, Project Report No.58.

Teel, T. L., and M. J. Manfredo. 2010. Understanding the diversity of public interests in wildlife conservation. Conservation Biology 24:128-139.

Thompson, A. W., A. Reimer, and L. S. Prokopy. 2015. Farmers' views of the environment: the influence of competing attitude frames on landscape conservation efforts. Agriculture and Human Values 32:385-399.

Tickes, B. R., L. K. Cheatheam, and J. L. Stair. 1982. A comparison of selected rodenticides for the control of the common valley pocket gopher (Thomomys bottae). Proceedings of the Vertebrate Pest Conference 10:201-204.

Viers, J. H., J. N. Williams, K. A. Nicholas, O. Barbosa, I. Kotzé, L. Spence, L. B. Webb, A. Merenlender, and M. Reynolds. 2013. Vinecology: pairing wine with nature. Conservation Letters 6:287-299.

Wendt, C. A., and M. D. Johnson. 2017. Multi-scale analysis of barn owl nest box selection on Napa Valley vineyards. Agriculture, Ecosystems \& Environment 247:75-83.

Whittaker, D., J. J. Vaske, and M. J. Manfredo. 2006. Specificity and the cognitive hierarchy: value orientations and the acceptability of urban wildlife management actions. Society \& Natural Resources 19:515-530.

Winkler, K. J., J. H. Viers, and K. A. Nicholas. 2017. Assessing ecosystem services and multifunctionality for vineyard systems. Frontiers in Environmental Science 5:15.

Wood, B. J., and C. G. Fee. 2003. A critical review of the development of rat control in Malaysian agriculture since the 1960s. Crop Protection 22:445-461.

Submitted 31 October 2020

Accepted 14 January 2021

Associate Editor was J. Rudd 